ISSN 1392-3196 / e-ISSN 2335-8947

Zemdirbyste-Agriculture, vol. 107, No. 4 (2020), p. 353-358

DOI 10.13080/z-a.2020.107.045

\title{
Molecular characterization of Cucurbit aphid-borne yellows virus (CABYV) affecting cucurbits in Turkey
}

\author{
Serife TOPKAYA ${ }^{1}$, Cecile DESBIEZ ${ }^{2}$ \\ ${ }^{1}$ Gaziosmanpasa University, Faculty of Agriculture \\ 60000 Tokat, Turkey \\ E-mail: serife.topkaya@gop.edu.tr \\ ${ }^{2}$ INRAE, Pathologie Végétale \\ F-84140 Montfavet, France
}

\begin{abstract}
Cucurbit aphid-borne yellows virus (CABYV) causes yellowing symptoms on the older leaves of plants from several species in the Cucurbitaceae family. Previous phylogenetic analyses showed the existence of two major clades of CABYV isolates related to their geographic origin - Asian vs European-African (Mediterranean) groups. To provide an understanding of the molecular variability of CABYV in Turkey, surveys were performed in 2011 to 2015 to obtain plants infected by the virus in four provinces, where cucurbit cultivation is of economic importance for the country. One hundred and forty leaf samples of cucurbit plants showing virus-like symptoms: yellowing, mosaic, deformation on leaves and stunting, were collected from Antalya, Ankara and Burdur provinces during the 2011-2013 growing seasons and 40 leaf samples from Tokat province during the 2015 growing season. Five CABYV isolates, collected in Antalya, Hatay and Mugla provinces in 1994, were added to the analysis. The coat protein coding regions of $15 \mathrm{CABYV}$ isolates were amplified by reverse transcription-polymerase chain reaction (RT-PCR) using specific primers and sequenced. According to the sequence analyses, 11 isolates shared $99 \%$ nucleotide identity with isolates from Egypt, Slovenia and Montenegro, three isolates showed more than 99\% nucleotide identity with isolates from China, South Korea and Iran, and one isolate presented evidence of mixed infection. Neighbour-joining analyses based on the resultant sequences revealed that the Turkish CABYV isolates clustered in two distinct molecular groups: five isolates from 1994, six isolates from 2012-2013 and one from 2015 clustered in the Mediterranean group, whereas three isolates from 2012-2013 clustered in the Asian group. In addition, one isolate presented a mixed infection of the two groups.
\end{abstract}

Key words: Ankara, Antalya, Cucurbits, Cucurbit aphid-borne yellows virus, phylogenetic analysis.

\section{Introduction}

Cucurbits (Cucurbitaceae Juss.) are widely cultivated in fields, greenhouses and home gardens in all provinces of Turkey. Watermelon (Citrullus lanatus (Thunb.) Matsum. and Nakai), melon (Cucumis melo L.), squash (Cucurbita pepo L.) and cucumber (Cucumis sativus L.) are widely grown cucurbit species in the country (TUIK, http://www.tuik.gov.tr/). The members of the Cucurbitaceae family worldwide are affected by at least 59 well-characterized viruses, which are among the major factors limiting production (Lecoq, Desbiez, 2012). In Turkey, Watermelon mosaic virus (WMV), Zucchini yellow mosaic virus (ZYMV), Cucumber mosaic virus (CMV), Squash mosaic virus (SqMV), Cucumber green mottle mosaic virus (CGMMV) and Cucurbit aphid-borne yellows virus (CABYV) have been reported in different geographical regions (Yardımcı, Ozgonen, 2007; Topkaya, Ertunc, 2012; Kamberoğlu et al., 2016; Korkmaz et al., 2018; Topkaya et al., 2019; Yeşil, 2019).

CABYV is an important virus inducing yellowing symptoms on older leaves in cucurbit fields worldwide. The virus can cause serious yield losses in infected plants without any effect on fruit quality and is often found in mixed infections with other viruses, especially with potyviruses that share common insect vectors (MnariHattab et al., 2009; Kassem et al., 2013; Costa et al., 2019). CABYV is a member of the genus Polerovirus, in the family Luteoviridae. Like other poleroviruses, CABYV has isometric virions, encapsidating a singlestranded positive-sense RNA molecule of $5.7 \mathrm{~kb}$. The CABYV genome encodes six open reading frames (ORFs): ORFs 0,1 and $1-2$ are translated from the genomic RNA and ORF 3, 4 and 3-5 (readthrough protein) from sub-genomic RNA, using different frames

Please use the following format when citing the article:

Topkaya S., Desbiez C. 2020. Molecular characterization of Cucurbit aphid-borne yellows virus (CABYV) affecting cucurbits in Turkey. Zemdirbyste-Agriculture, 107 (4): 353-358. DOI 10.13080/z-a.2020.107.045 
for the overlapping ORFs 3 and 4 (Guilley et al., 1994). Besides, a small non-AUG ORF-initiated was recently found to be present in poleroviruses including CABYV and involved in long-distance movement (Smirnova et al., 2015). P0 protein is a suppressor of posttranscriptional gene silencing (PTGS) (Pfeffer et al., 2002). $P 1$ has regions of amino acid sequence similarity with serine proteases and genome-linked viral proteins (VPgs) of other poleroviruses, and P1-P2 has amino acid motifs typical of RNA-dependent RNA polymerases (RdRP) (Guilley et al., 1994; Mayo, Miller, 1999). P3 is a coat protein $(\mathrm{CP}), \mathrm{P} 4$ is a movement protein (MP) and $\mathrm{P} 3-\mathrm{P} 5$ is involved in transmission by aphids (Mayo, Miller, 1999).

CABYV was first reported in France in 1988, but it was later found to be already very common in samples that had been collected in 1982 (Lecoq et al., 1992). CABYV is present and usually highly prevalent in many cucurbit-growing areas including Asia and the whole Mediterranean region, whereas it has been reported in a few locations in the Americas and Oceania (Lecoq, Desbiez, 2012; Khanal, Ali, 2018; https:/www.cabi. org/isc). Like other poleroviruses, CABYV is limited to phloem tissues in infected cucurbit plants (Guilley et al., 1994). It is obligately transmitted in a persistent, circulative, non-propagative manner by a few aphid species (mostly Aphis gossypii), but is not mechanically transmissible (Lecoq et al., 1992; D'Arcy, Domier, 2005; Gray et al., 2014). CABYV infects cucurbit crops including melon, cucumber and squash (Lecoq et al., 1992). It has also been reported in some weeds, such as Capsella bursa-pastoris, Lamium amplexicaule, Senecio vulgaris, Ecballium elaterium, Bryonia dioica, Papaver rhoeas, Montia perfoliata and Crambre abyssinica (Lecoq et al., 1992; Mnari-Hattab et al., 2009; Knierim et al., 2010; Kassem et al., 2013), which can serve as virus reservoirs when no cucurbits are present in the field.

Full-length sequence data are available in the GenBank for CABYV isolates from several parts of the world as well as numerous partial sequences of CABYV isolates from different geographical regions. Recombinant isolates between CABYV and melon aphid-borne yellows virus, another cucurbit-infecting polerovirus, have been described in several Asian countries including Taiwan, Thailand and the Philippines (Knierim et al., 2010; 2014). A recombinant isolate between CABYV and an undetermined polerovirus has also been described in Brazil (Costa et al., 2019). Among non-recombinant isolates, two major molecular groups have been defined: basal Asian and Mediterranean (Kassem et al., 2013). Minor highly divergent groups are also present in eastern Asia (Kwak et al., 2018).

In Turkey, H. Lecoq identified the virus in 1994 in Adana province (Lecoq, Desbiez, 2012), but it was first reported by Yardimc1 and Ozgonen (2007) based on serological diagnostics in Isparta province. Recently, CABYV has been reported at very low rates in the Cukurova region (Kamberoğlu et al., 2016).

Until now, only limited research has been done on CABYV in Turkey and little molecular information was available about its molecular diversity in the country. Only two partial CABYV sequences were available in GenBank, from Vicia faba (RdRp coding region) and Cucurbita pepo (CP coding region) isolates collected in 2016. Therefore, the aim of the study was to characterize the molecular variability of Turkish CABYV isolates and the relationship with worldwide isolates, through determining partial coat protein (CP) nucleotide sequences.

\section{Materials and methods}

Virus isolates. The isolates analysed in this study were collected during the 2011-2013 seasons from major cucurbit growing fields in Ankara $(\mathrm{n}=80)$, Antalya $(\mathrm{n}=56)$, Burdur $(\mathrm{n}=4)$ and during the 2015 summer season in Tokat $(\mathrm{n}=40)$ provinces in Turkey. The collected samples showed virus-like symptoms on different cucurbit species (cucumber, squash, melon and watermelon) including mosaic, yellowing, stunting and mottling patterns. These samples were tested previously by double antibody sandwich enzyme-linked immunosorbent assay (DAS-ELISA) for the presence of major cucurbit-infecting viruses (CMV, WMV, ZYMV, SqMV and Papaya ringspot virus) (Topkaya et al., 2019), but they had not yet been tested for the presence of CABYV. Also, five Turkish CABYV-infected plants (TR94-20, TR94-33, TR94-36, TR94-39 and TR94-86) collected in 1994 and stored as dried leaf material on calcium chloride were provided by H. Lecoq (Table 1).

Molecular and phylogenetic analysis. The presence of CABYV in the samples collected in 20112015 was assessed by molecular methods. Total RNA was extracted from the leaf tissue according to Astruc et al. (1996). Reverse transcription-polymerase chain reaction (RT-PCR) was performed using primers CABYVCE9 (5'-GAATACGGyCGCGGCTAGrAATC-3') (Kassem et al., 2007) and CABYV-KN-3' (5'-CCGTTCCCCTTGTAGAGGAT-3'). A two-step RTPCR analysis was performed to amplify a $534 \mathrm{nt}$ fragment of the coat protein-region of the CABYV isolates. For the first step, i.e. reverse transcription, a mixture containing $2.5 \mu \mathrm{l}$ total RNA, $4 \mu \mathrm{l}$ 5X RT-buffer, $0.5 \mu \mathrm{l}$ dNTPs (25 mM), $1 \mu$ l CABYV-KN 3' primer (10 pmol), $0.25 \mu \mathrm{l}$ AMV-RT (Promega) and $\mathrm{dH}_{2} \mathrm{O}$ was incubated at $42^{\circ} \mathrm{C}$ for $1 \mathrm{~h}$. Then, the PCR conditions were applied as $95^{\circ} \mathrm{C}$ for $5 \mathrm{~min}$ followed by 35 cycles of denaturation at $94^{\circ} \mathrm{C}$ for $30 \mathrm{~s}$, annealing at $55^{\circ} \mathrm{C}$ for $30 \mathrm{~s}$ and elongation at $72^{\circ} \mathrm{C}$ for $30 \mathrm{~s}$, and a final extension step at $72^{\circ} \mathrm{C}$ for $7 \mathrm{~min}$. After visualization on $1.5 \%$ agarose gel, positive PCR products (about $600 \mathrm{bp}$ ) for direct sequencing were sent to GenoScreen, France. The sequence analysis and comparisons were conducted using software MEGA $X$ (Kumar et al., 2018). Nucleotide sequences and deduced amino acid sequences were aligned with those from worldwide isolates using program Clustal $W$ (EMBIEBI, UK), included in software $M E G A X$. Phylogenetic trees were built using the neighbour-joining method (substitution model: $p$-distance method) with 1,000 bootstrap replicates with $M E G A X$. 
Table 1. Turkish cucurbit isolates, from which Cucurbit aphid-borne yellows virus (CABYV) sequences were obtained

\begin{tabular}{|c|c|c|c|c|c|c|}
\hline Province & District & Year & Samples code & Host & Symptom patterns & $\begin{array}{c}\text { GenBank } \\
\text { accession No. }\end{array}$ \\
\hline \multirow{7}{*}{ Ankara } & Ayaş & 2013 & AT1 & squash & deformation, mottling & MT219978 \\
\hline & \multirow{6}{*}{ Çubuk } & \multirow{6}{*}{2011} & $\mathrm{C} 5$ & squash & mosaic, yellowing & MT219979 \\
\hline & & & $\mathrm{C} 11$ & squash & mottling, deformation & MT219980 \\
\hline & & & $\mathrm{C} 12$ & squash & mottling, mosaic & MT219981 \\
\hline & & & $\mathrm{C} 16$ & melon & mottling & MT219982 \\
\hline & & & $\mathrm{C} 17$ & melon & mottling & MT219983 \\
\hline & & & C19 & pumpkin & yellowing, deformation & MT219984 \\
\hline \multirow{2}{*}{ Antalya } & \multirow{2}{*}{ Elmalı } & \multirow{2}{*}{2012} & E7 & melon & yellowing, deformation & MT219985 \\
\hline & & & Y22 & squash & yellowing, deformation & MT219986 \\
\hline Tokat & Center & 2015 & Tokat-CABYV & melon & yellowing, deformation & MT219987 \\
\hline Muğla & Fethiye & \multirow{5}{*}{1994} & TR94-20 & cucumber & unknown & MT219988 \\
\hline Antalya & Kale & & TR94-33 & squash & unknown & MT219989 \\
\hline Antalya & Kale & & TR94-36 & squash & unknown & MT219990 \\
\hline Antalya & & & TR94-39 & squash & unknown & MT219991 \\
\hline Hatay & Samandag & & TR94-86 & bottle gourd & unknown & MT219992 \\
\hline
\end{tabular}

\section{Results}

All samples were subjected to DAS-ELISA, and multiple infections by common cucurbit viruses (ZYMV and WMV) were detected (Topkaya et al., 2019). Among the 180 samples showing different symptoms, such as a mosaic pattern, mottling, deformation on leaf and fruit, yellowing, vein banding and stunting, collected from Ankara, Antalya, Burdur and Tokat provinces in Turkey and tested by RT-PCR for the presence of CABYV, positive results were obtained for a total of $21(12 \%)$ samples, one from Tokat and 20 from Antalya and Ankara provinces. CABYV was not found in the Burdur isolates. Most CABYV-infected isolates were also infected by other cucurbit-infecting viruses (Topkaya, Ertunc, 2012; Topkaya et al., 2019). Partial coat protein sequences were obtained for 11 samples collected between 2011 and 2015 as well as from the five isolates collected in 1994. Isolate C13 from Ankara presented double peaks, indicating infection by multiple variants. The remaining sequences (15) were deposited in the GenBank with accession numbers MT219978-MT219992 (Table 1).

To compare the sequences of the Turkish CABYV isolates (448 bp after sequence trimming) with other isolates from different parts of the world, phylogenetic analyses were performed with reported sequences from different countries. The features of the Turkish CABYV isolates are shown in Table 1.

The 15 CABYV isolates from this study and 35 sequences from the GeneBank were used for phylogenetic analyses (Fig.).

Isolates C16 (melon), C19 (pumpkin) and AT1 (squash) from Ankara province shared 99\% identity with those from China, Iran and South Korea and did not cluster with the other Turkish isolates. The isolates collected in 1994 and isolate Y22 from Antalya province shared 99\% nucleotide sequence identity with El Korean and Badr isolates from Egypt as well as with isolates from Montenegro and Slovenia in the "Mediterranean" CABYV clade. Isolate C5 from Ankara province was slightly distinct from the other isolates in the "Mediterranean" clade, but it shared more than 98\% sequence identity with Montenegro and Slovenia isolates. Thus, the Turkish CABYV isolates were found to belong to two molecular groups: the five isolates collected in 1994, six isolates from 2011-2013 and one isolate from Tokat (Tokat-CABYV) clustered in the Mediterranean group also including the GenBank isolate MK129536 from 2016, while three isolates from 20112013 clustered in the Asian group (Fig.).

Multiple alignments of the amino acid of partial coat protein sequences showed the same results as nucleotide sequences (data not shown). The Turkish CABYV isolates did not cluster according to their host, year or locality of collection. For example, the samples collected from Cubuk district of Ankara province clustered in different clades. The genetic distance between Turkish CABYV isolates and with isolates from different parts of the world was less than 0.05 , which indicated that they had a close genetic relationship. Genetic identity within each group (Asian vs Mediterranean) was above 97-98\%, while it was $95-96 \%$ between groups (Table 2).

\section{Discussion}

The data about the presence of CABYV in Turkey is still limited and fragmentary. Due to the similarity of yellowing symptoms induced by CABYV to those caused by other factors, such as biotic stresses or nutrient deficiencies, the presence of this virus has long been unnoticed in Turkey. The virus was reported using DAS-ELISA by Yardımc1 and Ozgonen (2007) in Isparta province, while Ozaslan et al. (2006) reported no CABYV infection in cucurbits grown in Gaziantep province. Kamberoğlu et al. (2016) observed a low prevalence $(0.6 \%)$ of $\mathrm{CABYV}$ in the Adana province in 2008-2010, whereas the virus was not observed in the Mersin province. Recently, Buzkan et al. (2017) have detected CABYV in Vicia faba in Tarsus district in the Mediterranean region of Turkey. In this study, the CABYV infection rate among the collected cucurbits was $12 \%$.

Results of the current study showed that the CABYV prevalence in some areas in Turkey could actually be rather high, and the agronomic impact of the virus should not be underestimated. Besides, results of our study showed that the Turkish CABYV isolates belonged to different molecular clades - "Asian" and "Mediterranean" (Fig.). This suggests that several introductions of CABYV have taken place in Turkey. 


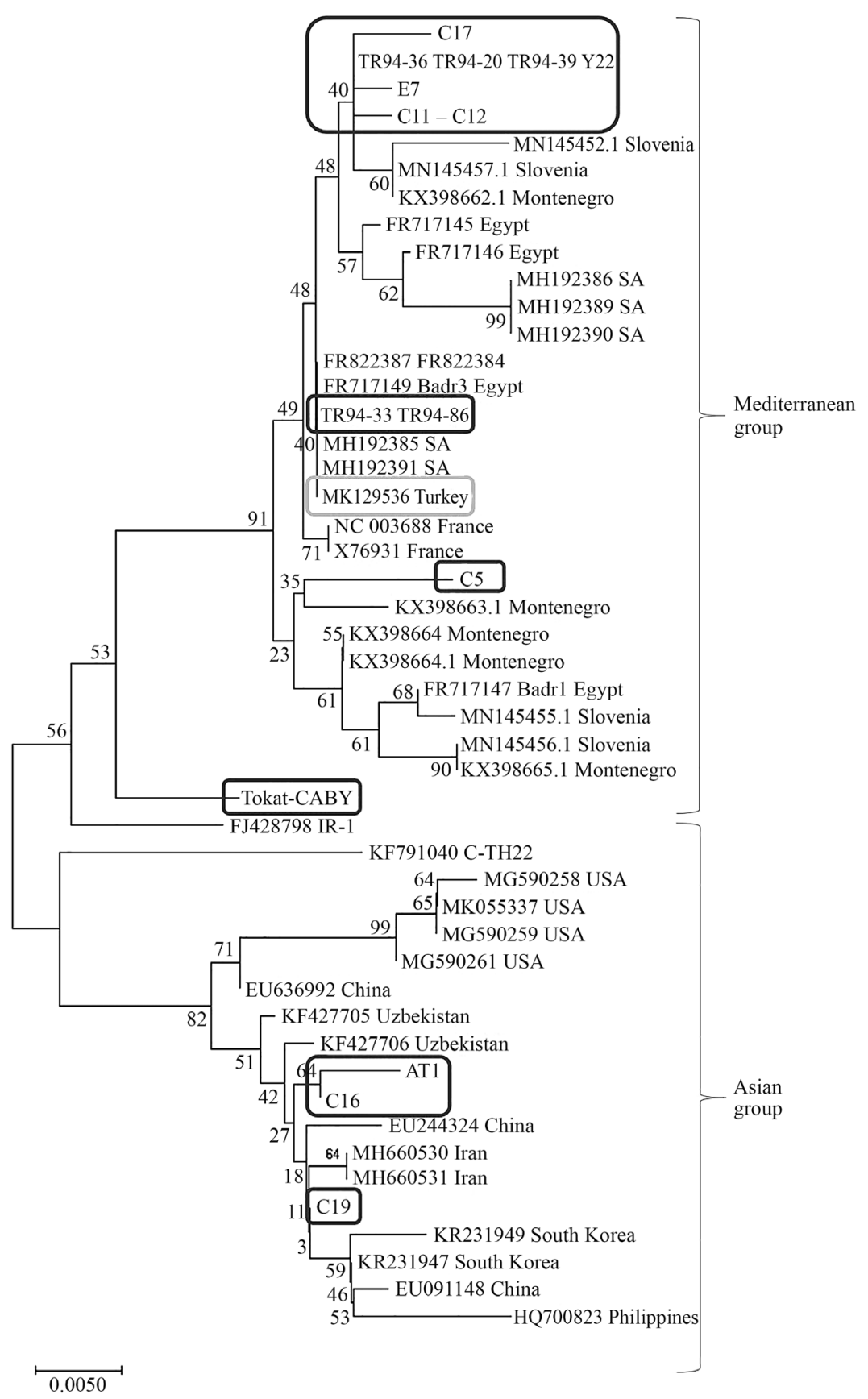

Notes. The evolutionary history was inferred using the neighbour-joining method (Saitou, Nei, 1987). The optimal tree with the sum of branch length $=0.17636371$ is shown. The percentage of replicate trees, in which the associated taxa clustered together in the bootstrap test (1000 replicates), are shown next to the branches. The tree is drawn to scale, with branch lengths in the same units as those of the evolutionary distances used to infer the phylogenetic tree. The scale bar represents a genetic distance of 0.005 . There were a total of 448 positions in the final dataset. Evolutionary analyses were conducted in software MEGA X (Kumar et al., 2018).

Figure. Phylogenetic tree of the CABYV isolates and reference isolates based on coat protein partial nucleotide sequences

Turkish isolates were closely related to isolates from Egypt in the Mediterranean group and from Iran in the Asian group. However, since the global knowledge on CABYV worldwide diversity remains very fragmentary, the relation between the genetic and geographic diversity is difficult to establish. Nevertheless, the evidence of multiple origins for CABYV populations in Turkey shows the importance of controlling long-distance virus dissemination through aphids' flights or through the exchange of infected plant material and/or plants carrying viruliferous aphids.

To our knowledge, the situation in Turkey constitutes the first case, where both CABYV clades are found in the same location and sometimes in the same plant (mixed infected isolate C13). This situation could favour the emergence of recombinants between the two clades that could have new biological properties and enhanced agronomic impact. The use of cucurbit 
Table 2. Nucleotide sequence identity (\%) in the coat protein (CP) sequences between CABYV isolates

\begin{tabular}{|c|c|c|c|c|c|c|c|c|c|c|c|c|c|c|c|c|c|c|c|c|c|}
\hline & Isolate (groups) & 1 & 2 & 3 & 4 & 5 & 6 & 7 & 8 & 9 & 10 & 11 & 12 & 13 & 14 & 15 & 16 & 17 & 18 & 2021 & 22 \\
\hline 1 & $\begin{array}{l}\text { MN145457_Slovenia } \\
\text { (Mediterrenean) }\end{array}$ & & & & & & & & & & & & & & & & & & & & \\
\hline 2 & $\begin{array}{l}\text { KX398662_Montenegro } \\
\text { (Mediterrenean) }\end{array}$ & 100 & & & & & & & & & & & & & & & & & & & \\
\hline 3 & $\begin{array}{l}\text { MK129536_Turkey } \\
\text { (Mediterrenean) }\end{array}$ & 99.3 & 99.3 & & & & & & & & & & & & & & & & & & \\
\hline 4 & C5 (Mediterrenean) & 98 & 98 & 98.7 & & & & & & & & & & & & & & & & & \\
\hline 5 & C11 (Mediterrenean) & 100 & 100 & 99.3 & 98 & & & & & & & & & & & & & & & & \\
\hline 6 & C12 (Mediterrenean) & 100 & 100 & 99.3 & 98 & 100 & & & & & & & & & & & & & & & \\
\hline 7 & C17 (Mediterrenean) & 100 & 100 & 99.3 & 98 & 100 & 100 & & & & & & & & & & & & & & \\
\hline 8 & E7 (Mediterrenean) & 100 & 100 & 99.3 & 98 & 100 & 100 & 100 & & & & & & & & & & & & & \\
\hline 9 & Y22 (Mediterrenean) & 100 & 100 & 99.3 & 98 & 100 & 100 & 100 & 100 & & & & & & & & & & & & \\
\hline 10 & $\begin{array}{l}\text { Tokat-CABY } \\
\text { (Mediterrenean) }\end{array}$ & 97.3 & 97.3 & 98 & 98 & 97 & 97.3 & 97.3 & 97.3 & 97.3 & & & & & & & & & & & \\
\hline 11 & TR94-20 (Mediterrenean) & 100 & 100 & 99.3 & 98 & 100 & 100 & 100 & 100 & 100 & 97.3 & & & & & & & & & & \\
\hline 12 & TR94-33 (Mediterrenean) & 99.3 & 99.3 & 100 & 98.7 & 99 & 99.3 & 99.3 & 99.3 & 99.3 & 98 & 99.3 & & & & & & & & & \\
\hline 13 & TR94-36 (Mediterrenean) & 100 & 100 & 99.3 & 98 & 100 & 100 & 100 & 100 & 100 & 97.3 & 100 & 99.3 & & & & & & & & \\
\hline 14 & TR94-39 (Mediterrenean) & 100 & 100 & 99.3 & 98 & 100 & 100 & 100 & 100 & 100 & 97.3 & 100 & 99.3 & 100 & & & & & & & \\
\hline 15 & TR94-86 (Mediterrenean) & 99.3 & 99.3 & 100 & 98.7 & 99 & 99.3 & 99.3 & 99.3 & 99.3 & 98 & 99.3 & 100 & 99.3 & 99.3 & & & & & & \\
\hline 16 & $\begin{array}{l}\text { KF427706_Uzbekistan } \\
\text { (Asian) }\end{array}$ & 95.3 & 95.3 & 95.3 & 95.3 & 95 & 95.3 & 95.3 & 95.3 & 95.3 & 97.3 & 95.3 & 95.3 & 95.3 & 95.3 & 95.3 & & & & & \\
\hline 17 & $\begin{array}{l}\text { KR231949_South_Korea } \\
\text { (Asian) }\end{array}$ & 95.3 & 95.3 & 95.3 & 95.3 & 95 & 95.3 & 95.3 & 95.3 & 95.3 & 97.3 & 95.3 & 95.3 & 95.3 & 95.3 & 95.3 & 100 & & & & \\
\hline 18 & $\begin{array}{l}\text { KR231947_South_Korea } \\
\text { (Asian) }\end{array}$ & 95.3 & 95.3 & 95.3 & 95.3 & 95 & 95.3 & 95.3 & 95.3 & 95.3 & 97.3 & 95.3 & 95.3 & 95.3 & 95.3 & 95.3 & 100 & 100 & & & \\
\hline 19 & MH660530_Iran (Asian) & 95.3 & 95.3 & 95.3 & 95.3 & 95 & 95.3 & 95.3 & 95.3 & 95.3 & 97.3 & 95.3 & 95.3 & 95.3 & 95.3 & 95.3 & 100 & 100 & 100 & & \\
\hline 20 & AT1 (Asian) & 94.6 & 94.6 & 594.6 & 94.6 & 95 & 94.6 & 94.6 & 94.6 & 94.6 & 96.6 & 94.6 & 94.6 & 94.6 & 94.6 & 94.6 & 99 & 98.7 & 98.7 & 98.7 & \\
\hline 21 & C16 (Asian) & 95.3 & 95.3 & 95.3 & 95.3 & 95 & 95.3 & 95.3 & 95.3 & 95.3 & 97.3 & 95.3 & 95.3 & 95.3 & 95.3 & 95.3 & 99 & 99.3 & 99.3 & 99.399 .3 & \\
\hline 22 & C19 (Asian) & 95.3 & 95.3 & 95.3 & 95.3 & 95 & 95.3 & 95.3 & 95.3 & 95.3 & 97.3 & 95.3 & 95.3 & 95.3 & 95.3 & 95.3 & 100 & 100 & 100 & 10098.799 .3 & \\
\hline
\end{tabular}

Note. There were a total of 448 positions in the final dataset; evolutionary analyses were conducted in software MEGA $X$ (Kumar et al., 2018).

cultivars resistant to CABYV and other viruses can be a very efficient way to control viral infections in crops (Dogimont et al., 1996; Lecoq, Desbiez, 2012), but the specificity of the resistance towards the diversity of the virus (Table 2) has to be estimated.

\section{Conclusion}

This is the first study of the molecular variability of Cucurbit aphid-borne yellows virus (CABYV) in Turkey. It helps to further understand the genetic diversity and evolution of CABYV isolates infecting cucurbit plants in Turkey. Results of the current study also demonstrate that Turkish CABYV isolates belong genetically to both the Mediterranean and the Asian group.

Further studies on the variability, biological properties and interaction with other viruses are needed.

Received 07112019 Accepted 30062020

\section{References}

1. Astruc N., Marcos J. F., Macquarre G., Candresse T. Pallás V. 1996. Studies on the diagnosis of hop stunt viroid in fruit trees: identification of new hosts and application of a nucleic acid extraction procedure based on non-organic solvents. European Journal of Plant Pathology, 102: 837846. https://doi.org/10.1007/BF01877053

2. Buzkan N., Arpaci B. B., Apalak A. 2017. First report of Cucurbit aphid-borne yellows virus in Vicia faba. New Disease Reports, 35: 13.

https://doi.org/10.5197/j.2044-0588.2017.035.013

3. Costa T. M., Blawid R., Aranda M. A., Freitas D. M. S., Andrade G. P., Inoue-Nagata A. K., Nagata T. 2019. Cucurbit aphid-borne yellows virus from melon plants in Brazil is an interspecific recombinant. Archives of Virology, 164 (1): 249-254. https://doi.org/10.1007/s00705-018-4024-2
4. D'Arcy C. J., Domier L. L. 2005. Family Luteoviridae. Fauquet C. M. et al. (eds). Virus taxonomy, the $8^{\text {th }}$ report of the ICTV. Elsevier, Academic Press, p. 891-900.

5. Dogimont C., Slama S., Martin J., Lecoq H., Falk B. W. 1996. Sources of resistance to cucurbit aphid-borne yellows luteovirus in a melon germplasm collection. Plant Disease, 80: 1379-1382. https://doi.org/10.1094/PD-80-1379

6. Gray S., Cilia M., Ghanim M. 2014. Circulative, "nonpropagative" virus transmission: an orchestra of virus-, insect-, and plant-derived instruments. Advances in Virus Research, 89: 141-199. https://doi.org/10.1016/B978-0-12-800172-1.00004-5

7. Guilley H., Wipf-Scheibel C., Richards K., Lecoq H., Jonard G. 1994. Nucleotide sequence of cucurbit aphidborne yellows luteovirus. Virology, 202: 1012-1017. https://doi.org/10.1006/viro.1994.1429

8. Kamberoğlu M. A., Caliskan A. F., Desbiez C. 2016. Current status of some cucurbit viruses in Cukurova region (Adana and Mersin Provinces) of Turkey and molecular characterization of zucchini yellow mosaic virus isolates. Romanian Biotechnological Letters, 21: 11709-11719.

9. Kassem M. A., Sempere R. N., Juarez M., Aranda M. A., Truniger V. 2007. Cucurbit aphid-borne yellows virus is prevalent in field-grown cucurbit crops of southeastern Spain. Plant Disease, 91: 232-238. https://doi.org/10.1094/PDIS-91-3-0232

10. Kassem M. A., Juarez M., Gómez P., Mengual C. M., Sempere R. N., Plaza M., Elena S. F., Moreno A., Fereres A., Aranda M. A. 2013. Genetic diversity and potential vectors and reservoirs of Cucurbit aphid-borne yellows virus in Southeastern Spain. Phytopathology, 103: 1188-1197. https://doi.org/10.1094/PHYTO-11-12-0280-R

11. Khanal V., Ali A. 2018. First report of Cucurbit aphid-borne yellows virus infecting Cucurbita pepo in Oklahoma. Plant Disease, 102: 1046. https://doi.org/10.1094/PDIS-10-17-1675-PDN

12. Knierim D., Deng T. C., Tsai W. S., Green S. K., Kenyon L. 2010. Molecular identification of three distinct Polerovirus species and a recombinant Cucurbit aphid-borne yellows virus strain infecting cucurbit crops in Taiwan. Plant Pathology, 59: 991-1002.

https://doi.org/10.1111/j.1365-3059.2010.02327.x 
13. Knierim D., Tsai W. S., Maiss E., Kenyon L. 2014. Molecular diversity of poleroviruses infecting cucurbit crops in four countries reveals the presence of members of six distinct species. Archives of Virology, 159: 1459-1465. https://doi.org/10.1007/s00705-013-1939-5

14. Korkmaz F., Topkaya Ş., Yanar Y. 2018. Determination of viruses in cucurbits growing areas from Tokat. Gaziosmanpasa Journal of Scientific Research, 7 (2): 46-56 (in Turkish). https://dergipark.org.tr/en/download/articlefile/521059

15. Kumar S., Stecher G., Li M., Knyaz C., Tamura K. 2018. MEGA X: molecular evolutionary genetics analysis across computing platforms. Molecular Biology and Evolution, 35 (6): 1547-1549. https://doi.org/10.1093/molbev/msy096

16. Kwak H. R., Lee H. J., Kim E. A., Seo J. K., Kim C. S., Lee S. G., Kim J. S., Choi H. S., Kim M. 2018. Complete genome sequences and evolutionary analysis of Cucurbit aphid-borne yellows virus isolates from melon in Korea. Plant Pathology Journal, 34: 532-543.

17. Lecoq H., Desbiez C. 2012. Viruses of cucurbit crops in the Mediterranean region: an ever-changing picture. Advances in Virus Research, 84: 67-126. https://doi.org/10.1016/B978-0-12-394314-9.00003-8

18. Lecoq H., Bourdin D., Wipf-Scheibel C., Bon M., Lot H., Lemaire O., Herrbach E. 1992. A new yellowing disease of cucurbits caused by a luteovirus, Cucurbit aphid-borne yellows virus. Plant Pathology Journal, 41: 749-761. https://doi.org/10.1111/j.1365-3059.1992.tb02559.x

19. Mayo M. A., Miller W. A. 1999. The structure and expression of luteovirus genomes. Smith H. G., Barker H. (eds). The Luteoviridae. CABI Publishing, p. 23-42.

20. Mnari-Hattab M., Gauthier N., Zouba A. 2009. Biological and molecular characterization of the Cucurbit aphid-borne yellows virus affecting cucurbits in Tunisia. Plant Disease, 93: 1065-1072. https://doi.org/10.1094/PDIS-93-10-1065
21. Ozaslan M., Aytekın T., Bas B., Kilıc I. H., Afacan I. D., Dag D. S. 2006. Virus diseases of cucurbits in GaziatepTurkey. Plant Pathology Journal, 5: 24-27. https://doi.org/10.3923/ppj.2006.24.27

22. Pfeffer S., Dunoyer P., Heim F., Richards K. E., Jonard G., Ziegler-Graff V. 2002. P0 of beet Western yellows virus is a suppressor of posttranscriptional gene silencing. Journal of Virology, 76 (13): 6815-6824. https://doi.org/10.1128/JVI.76.13.6815-6824.2002

23. Saitou N., Nei M. 1987. The neighbor-joining method: a new method for reconstructing phylogenetic trees. Molecular Biology and Evolution, 4 (4): 406-425.

24. Smirnova E., Firth A. E., Miller W. A., Scheidecker D., Brault V., Reinbold C., Rakotondrafara A. M., Chung B. Y.-W., Ziegler-Graff V. 2015. Discovery of a small non-AUG-initiated ORF in Poleroviruses and Luteoviruses that is required for long-distance movement. PLoS Pathogens, 11 (5): e1004868. https://doi.org/10.1371/journal.ppat.1004868

25. Topkaya S., Ertunc F. 2012. Current status of virus infections in cucurbit plantations in Ankara and Antalya provinces. Proceedings of the $10^{\text {th }}$ EUCARPIA Meeting on Genetics and Breeding of Cucurbitaceae, p. 759-762.

26. Topkaya S., Desbiez C., Ertunc F. 2019. Presence of cucurbit viruses in Ankara and Antalya province and molecular characterization of coat protein gene of zucchini yellow mosaic virus Turkish isolates. Fresenius Environmental Bulletin, 28 (4): 2442-2449.

27. Yardimc1 N., Ozgonen H. 2007. First report of Cucurbit aphid-borne yellows virus in Turkey. Australasian Plant Disease Notes, 2: 59. https://doi.org/10.1071/DN07024

28. Yeşil S. 2019. Some virus diseases of edible seed squash (Cucurbita pepo L.) in Aksaray Province, Turkey. Yuzuncu Yil University Journal of Agricultural Sciences, 29 (spec. iss.): 63-71. https://doi.org/10.29133/yyutbd.476052

\title{
Amarų pernešamo moliūgų viruso (CABYV) molekulinis apibūdinimas Turkijoje
}

\author{
S. Topkaya ${ }^{1}$, C. Desbiez ${ }^{2}$ \\ ${ }^{1}$ Gaziosmanpasa universiteto Žemès ūkio fakultetas, Turkija \\ ${ }^{2}$ Prancūzijos nacionalinio žemès ūkio, maisto ir aplinkos tyrimų instituto (INRAE) \\ Augalų patologijos skyrius
}

\section{Santrauka}

Amarų pernešamas moliūgų virusas (CABYV) sukelia kai kurių moliūginių augalų rūšių senesnių lapų pageltimą. Anksčiau atliktos filogenetinès analizès parodè, kad egzistuoja du pagrindiniai CABYV izoliatų tipai, susiję su jų geografine kilme - Azijos ir Europos bei Afrikos (Viduržemio jūros regiono) grupès. Siekiant suprasti CABYV molekulinị kintamumą, 2011-2015 m. Turkijoje keturiose provincijose, kuriose moliūgų auginimas yra ekonomiškai svarbus šaliai, buvo tirti virusu užkrèsti augalai. Auginimo sezono metu 140 moliūgų lapų su į virusą panašiais simptomais, tokiais kaip pageltimas, mozaika, deformacija ir sunykimas, 2011-2013 m. buvo surinkti Antalijos, Ankaros ir Burduro provincijose; 40 lapų buvo surinkti Tokato provincijoje $2015 \mathrm{~m}$. İ analizę buvo itraukti ir 5 CABYV izoliatai, $1994 \mathrm{~m}$. surinkti Antalijoje, Hatay ir Mugla provincijose. Penkiolikos CABYV izoliatų kapsidès baltymus koduojančios sritys naudojant specifinius pradmenis buvo amplifikuotos atvirkštinès transkripcijos polimerazès grandinine reakcija (AT-PGR) ir sekvenuotos. Sekos analizè parodè, kad 11 izoliatų nukleotidų sekos 99 \% buvo identiškos su izoliatais iš Egipto, Slovėnijos ir Juodkalnijos, 3 izoliatų sekos daugiau nei 99 \% sutapo su izoliatais iš Kinijos, Pietų Korèjos ir Irano, o 1 izoliatui buvo būdinga mišri infekcija.

Tyrimo rezultatai parode, kad Turkijos CABYV izoliatai pasiskirste ị dvi grupes: penki 1994 m. surinkti izoliatai, šeši 2012-2013 m. surinkti izoliatai ir vienas 2015 m. surinktas izoliatas pateko ị Viduržemio jūros regiono grupę, o trys 2012-2013 m. surinkti izoliatai - ị Azijos grupę. Be to, vienam izoliatui buvo būdinga mišri dviejų grupių infekcija.

Reikšminiai žodžiais: Ankara, Antalija, fillogenetinė analizè, moliūgai, amarų pernešamas moliūgų virusas. 